\title{
Ecological traits of fish assemblages from Mediterranean Europe and their responses to human disturbance
}

\section{T. FERREIRA \& J. OLIVEIRA}

Departamento de Engenharia Florestal, Instituto Superior de Agronomia, Universidade Técnica de Lisboa, Lisboa, Portugal

\section{N. CAIOLA \& A. DE SOSTOA}

Departamento de Biologia Animal, Faculdad de Biologia, Universidade de Barcelona, Barcelona, Spain

\section{F. CASALS}

Departamento de Ecologia Animal, Universidade de Lleida, Lleida, Spain

\section{R. CORTES}

Departamento Florestal, Universidade de Trás-os-Montes e Alto Douro, Vila Real, Portugal

\section{A. ECONOMOU \& S. ZOGARIS}

Hellenic Centre for Marine Research, Institute of Inland Waters, Attiki, Greece

\section{GARCIA-JALON}

Departamento de Engenieria Florestal, ETSI Montes, Madrid, Spain

\section{ILHÉU}

Departamento de Ecologia, Universidade de Évora, Évora, Portugal

F. MARTINEZ-CAPEL

Departamento de Ingenieria Hidraulica y Medio Ambiente, Escuela Politecnica Superior de Gandia, Valencia, Spain

D. PONT \& C. ROGERS

Laboratoire d'Ecologie des Hydrosystèmes Fluviaux, Université Claude Bernard Lyon 1, Villeurbanne cedex, France

\author{
J. PRENDA \\ Departamento de Ecologia, Universidad de Huelva, Huelva, Spain
}

Correspondence: Prof. Teresa Ferreira, Departamento de Engenharia Florestal, Instituto Superior de Agronomia, Universidade Técnica de Lisboa, Tapada da Ajuda 1349-017 Lisboa, Portugal (e-mail: terferreira@isa.utl.pt) 
Abstract Mediterranean river systems are characterised by more diverse fish assemblages and regional ecological processes compared with the rest of Europe. A data set from Mediterranean France, Iberia and Greece ( 2000 sites) was used to describe the characteristics of fish assemblages, explore their responses to anthropogenic disturbance and analyse the implications for river quality assessment. There was a southwards decline in species richness per site, but endemicity and proportion of alien species increased. Sites in the eastern Mediterranean had higher endemicity, lower site richness and lower number of alien species than sites in western Mediterranean Europe. Assemblage composition differed between Mediterranean sub-regions, but was dominated by three major fish types: a salmonid fish type common throughout the study area and two cyprinid-dominated fish types (in some sub-regions, Salmo trutta L. is present but not numerically dominant), corresponding to a gradient in hydrological and temperature regimes. Metric responses to perturbation were compared with those found at the European (larger scale) and basin (smaller scale) levels. Overall metric response was weaker in this Mediterranean application. The best responses to human pressure were usually obtained with abundance-based metrics and included the contribution of naturalised alien species. Some widespread alien species contributed to the response to anthropogenic alteration (notably Cyprinus carpio L. and Lepomis gibbosus (L.)).

KEYWORDS: alien species, fish metrics, fish types, guilds, human impacts, Mediterranean streams.

\section{Introduction}

Hydrological variability of Mediterranean-type regions profoundly determines the life forms and life cycles of aquatic organisms, as well as ecological processes (Blondel \& Aronson 1999; Gasith \& Resh 1999). Fish fauna from these heterogeneous ecosystems must frequently survive under alternating scenarios of too much or too little water with a few intermediate but crucial periods of investment in recruitment and growth. Under these conditions, fishes tend to have short life spans, rapid growth rates, high fecundity and early sexual maturity and spawning, as well as generalist and opportunistic feeding strategies (e.g. Granado-Lorencio 1996; Pires, Cowx \& Coelho 2001; Vila-Gispert, Moreno-Amich \& García-Berthou 2002).

The spatial and temporal environmental variability is exacerbated by a long history of human-induced pressures. Mediterranean-type regions generally experience limited water availability during part of the year, usually overcome by water storage in reservoirs, water abstraction from ground and surface sources and water transfers (Davies, Thoms, Walker, O'Keefe \& Gore 1994). Compared with more northern European rivers, anthropogenic disturbance frequently focuses on water quality and habitat modification; in Mediterranean ecosystems, these alterations are determined or amplified by human-related changes in the amount and periodicity of water availability to organisms. The robustness of these aquatic ecosystems and of their biological assemblages to naturally harsh and variable hydrological conditions make them resilient in the short-term to human pressure. However, over longer time periods they are vulnerable to continuous and cumulative human-induced changes (Matthews \& Marsh-Matthews 2003). It is therefore important to develop reliable indicators of ecosystem health for Mediterranean rivers.

The European FAME project developed a multimetric index based on fish assemblages to assess the ecological quality of European rivers, including the Mediterranean region (Pont, Hugueny, Beier, Goffaux, Melcher, Noble, Rogers, Roset \& Schmutz 2006). However, the taxonomic variability of fish assemblages found in these systems was so high that it reduced the number of available reference sites per fish type to a point that a site-based approach could not be applied in southernmost areas of Iberia and Greece (Pont et al. 2006). Previous attempts to develop metric indices for the Mediterranean regions also dealt with this limitation (Ferreira, Cortes, Godinho \& Oliveira 1996; Oliveira \& Ferreira 2002) with various degrees of success, but only at smaller regional scales. To provide an accurate assessment of the ecological status of rivers in the Mediterranean region, it is necessary to establish their characteristics and fish assemblages, and whether or not they present a common pattern.

The paper describes an approach to address this need using fish assemblage data from a range of Mediterranean rivers. The response of Mediterranean fish assemblages to human disturbance was also assessed using metrics developed within the wider European FAME project (Noble, Cowx, Goffaux \& Kestemont 2007; Roset, Grenouillet, Goffaux, Pont \& Kestemont 2007), as the foundation for further 
development of fish-based ecological quality assessment in the Mediterranean region.

\section{Methods}

Data on fish assemblages, environmental characteristics and human impacts were collected from 1989 sites representing 15 river regions from Portugal, Spain, France and Greece (Fig. 1). Although not distributed evenly, the available sites represent a wide range of Mediterranean conditions, covering large areas in western, central and north-eastern Iberia, southern France and western Greece. About half of the sites were truly Mediterranean (after Blondel \& Aronson 1999) (Fig. 1). Mediterranean sites retained for the analyses were generally characterised by small- to medium-size catchments (less than $500 \mathrm{~km}^{2}$ ), mean annual temperature (MAT) ranging from 10 to $18{ }^{\circ} \mathrm{C}$, mean annual rainfall (MAR) ranging from 600 to $1300 \mathrm{~mm}$ and an altitude below $800 \mathrm{~m}$. Fish were sampled by electric fishing according to CEN 14011 standards (CEN 2003), and all sites were wadeable. Environmental and human impact variables were collected either in situ or from national geographical information systems.

To establish reference conditions of species assemblage types, hierarchical cluster analysis was performed on a group of low impacted (termed calibration) sites. These have a low human pressure classification of 1 and 2 (range 1-5) on each of five core variables (as defined by Degerman, Beier, Breine, Melcher, Quataert, Rogers, Roset \& Simoens 2007): connectivity of the river segment, hydrological regime, morphological condition of the site, level of toxic and acidic substances and level of nutrients and organic matter. Overall, 293 low impacted sites were available. Fish density data were $\log (x+1)$ transformed and analysed using squared Euclidean distance and Ward's method of clustering.

Multiple discriminant analysis was used to allocate non-calibration sites to river types. Environmental data were transformed to ensure normality and the



Figure 1. Location of sites from Southern Europe database. Also shown is a line roughly separating the Mediterranean part according to Blondel \& Aronson (1999). homogeneity of variance tested. The environmental variables retained in the model were catchment size, altitude, longitude, latitude, MAT, MAR, gradient and wetted width of the river channel. Spearman rank correlations were used to study the response to disturbance of the selected metrics for: (a) an European fish-based index (Pont et al. 2006); (b) the European spatially based approach (Melcher, Schmutz, Haidvogl \& Moder 2007); and (c) a data set from Iberia (Ferreira, Caiola, Casals, Oliveira \& Sostoa 2007). The rank correlation was complemented by Mann-Whitney $U$-tests to confirm significant differences between minor-to-slight alteration (classification of 1-2) and moderate-to-severe alteration (classification $>2$ ). All analyses were performed using STATISTICA 6.0 software (StatSoft, Inc., Tulsa, OK, USA).

\section{Results}

Fifty-one percent of the sites (1004) were considered to belong to the Mediterranean bioclimatic region. Ninety-one fish species were caught (87 in Mediterranean only sites), of which 17 were alien. Most native species were endemic (Table 1). There is a southwards decrease in richness per site, but an increase in endemicity and in the proportion of alien species. The eastern Mediterranean area, represented by 110 Greek sites, presented a higher endemicity $(50 \%)$ and a lower number of alien species than in western Mediterranean Europe (Table 1).

In the western Mediterranean, most minimally disturbed sites had four or less species, while in the eastern Mediterranean most sites had only one or two species (Fig. 2). Assemblage composition differed between and within Mediterranean sub-areas (Fig. 3), probably in accordance with physical and physiographic heterogeneity of the river systems. Mediterranean France supported more widely distributed species, while only a few species occur in more than $20 \%$ of sites in more southern areas, indicating a higher degree of basin-specific assemblages, especially for Greece. Salmonid-type sites (those where Salmo trutta L., was present or dominant) were common throughout the Mediterranean area (Fig. 3). Different species of cyprinids, e.g. of the genera Barbus, Chondrostoma, Leuciscus, Rutilus, Squalius, Pseudophoxinus and Tropidophoxinellus, characterised the cyprinidtype fish assemblages. In France, the absence of physical barriers promoted the occurrence of typical central European species such as Barbus barbus (L.) and Rutilus rutilus (L.).

Superimposed on this scenario is a strong influence of alien species (Table 1), notably Lepomis gibbosus 
Table 1. Total number of sites (and available calibration sites), total number of species, percentage of endemic species in total of natives, average richness per site (and range) and average alien species per site in total of species, for Europe (FIDES database, Beier, Degerman, Melcher, Rogers \& Wirlöf 2007), Southern Europe and only Mediterranean sites (MED database)

\begin{tabular}{lccccc}
\hline & $\begin{array}{c}\text { Number of sites } \\
\text { (calibration sites) }\end{array}$ & $\begin{array}{c}\text { Total number } \\
\text { of species }\end{array}$ & $\begin{array}{c}\text { Endemic } \\
\text { species }(\%)\end{array}$ & $\begin{array}{c}\text { Site richness } \\
(\text { range })\end{array}$ & $\begin{array}{c}\text { Alien species } \\
(\%)\end{array}$ \\
\hline All Europe (FIDES) & $12679(2418)$ & 329 & $30.9^{*}$ & $5.0(0-29)$ & 15.4 \\
Southern Europe & $1989(868)$ & 91 & 45.9 & $2.8(0-19)$ & 18.7 \\
Mediterranean Europe & $1014(293)$ & 87 & 47.9 & $3.4(0-19)$ & 19.6 \\
France & $154(83)$ & 42 & 7.1 & $5.1(0-19)$ & 35.7 \\
Spain & $491(74)$ & 42 & 39.5 & $2.3(0-10)$ & 23.9 \\
Portugal & $249(72)$ & 34 & 36.0 & $4.3(0-12)$ & $2.5(0-6)$ \\
Greece & $110(64)$ & 28 & 50.0 & 2.5 & 10.7 \\
\hline
\end{tabular}

Data for specific countries are only for Mediterranean sites. Calibration sites (= sites having conditions of minimal disturbance) are those scoring 1 or 2 in the five core variables used to evaluate human pressure (see Methods for explanation).

*Average endemicity from European ichthyoregions (Melcher et al. 2007).
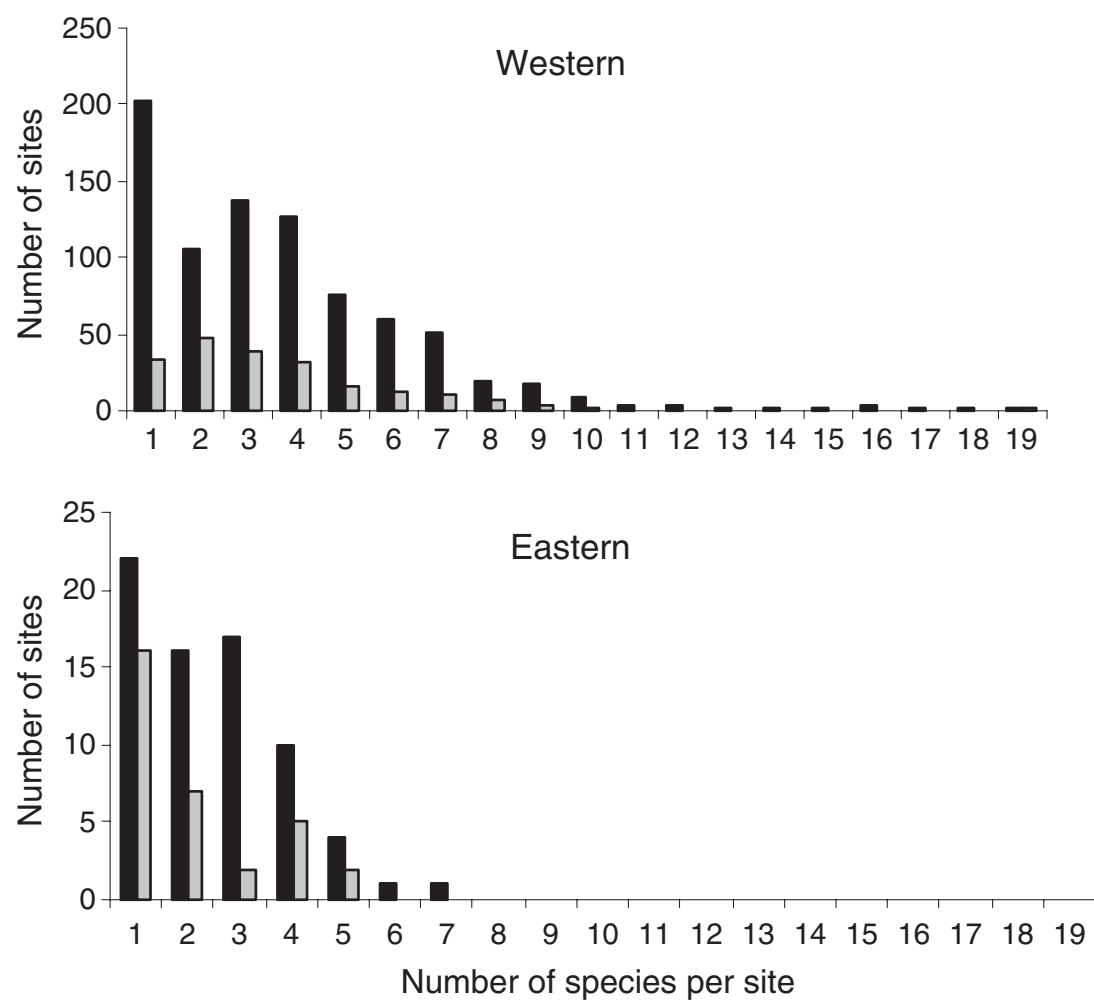

Figure 2. Fish richness in all sites (bold) and in calibration sites (shaded) in western Mediterranean (France and Iberia) and eastern Mediterranean (Greece).

(L.), which is particularly widespread in western Iberia, even in relatively unimpacted sites (Fig. 3). The number of alien species generally increased with human pressure (e.g. L. gibbosus and Cyprinus carpio L.) and its proportion in the calibration sites was significantly lower than in the non-calibration sites (Mann-Whitney $U$ rank test, $P<0.05$ ). Alien species seemed to be additive to natives in western Mediterranean rivers but not in eastern Mediterranean ones. At a considerable proportion of the Mediterranean sites (11.2\%), some of which were pre-classified as minimally impacted, all native species have been replaced by aliens.

Three large groups and five subgroups were discriminated by clustering (Fig. 4 and Table 2). Salmo trutta occurs as exclusive or dominant in group 1 (which is present in all countries and all parts of the Mediterranean area). Group 2 includes fish assemblages from France, eastern Spain and Greece 


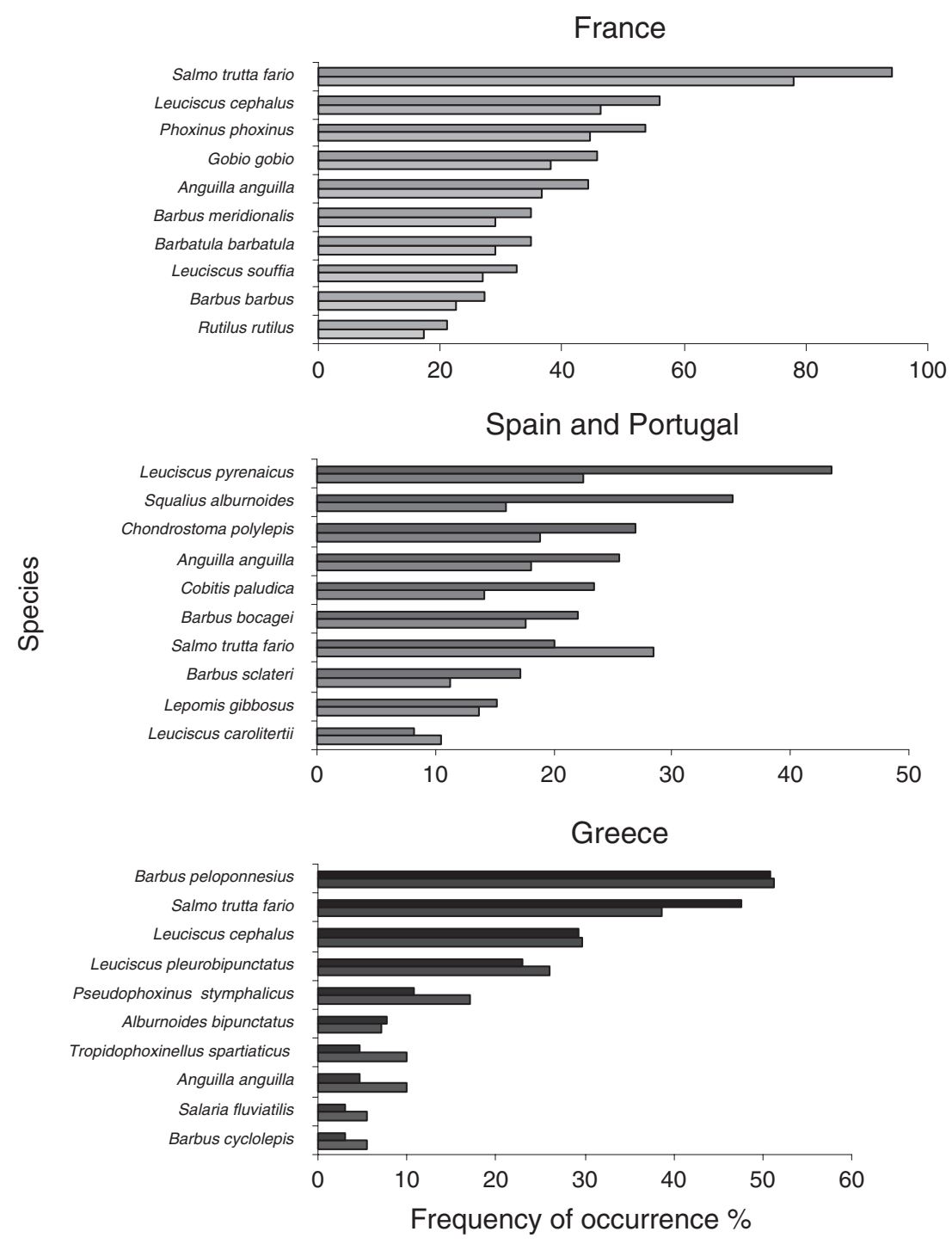

Figure 3. Ten top species having the highest frequency of occurrence (as the percentage of sections where the species was recorded) in the Mediterranean parts of France, Iberia and Greece. Black bars represent the calibration sites and shaded bars the total number of sites.

dominated by cyprinids, such as Barbus meridionalis Risso, Phoxinus phoxinus (L.), Leuciscus cephalus (L.) or Leuciscus souffia Risso; in this group, S. trutta can be present but is not numerically dominant. Group 3 includes sites from western, central and southern Iberia, dominated by various basin-specific cyprinid species such as Barbus bocagei Steindachner, Barbus microcephalus Almaça, Leuciscus pyrenaicus (Günther) and Squalius alburnoides (Steindachner). Overall, the three groups and their subdivisions displayed altitudinal and climatic gradients (Fig. 5) because Mediterranean areas include both cold water and warm water (permanent or intermittent) reaches. In addition, zoogeographical factors act simultaneously with the environmental drivers - groups G3A and G2A include sites only from Portugal and France respectively.

The best discriminant (canonical standardised) coefficients were altitude $(-0.78)$, MAT $(0.82)$ and MAR $(-0.76)$ for axis 1 , and MAR (0.72) for axis 2. Environmental correlation with the canonical axes was higher with MAR $(-0.54)$ and gradient $(-0.49)$ for axis 1, and MAT (0.46) for axis 2. The first two axes were significant $(P<0.01)$ and their cumulative variance was $79 \%$. The percentage of predicted/ observed ratio allocation of sites was $81 \%$ for group $1,70 \%$ for group 2 and $78 \%$ for group 3 .

Overall, metric response was weak (Table 3), especially in group 3 . The metrics showing the strongest 


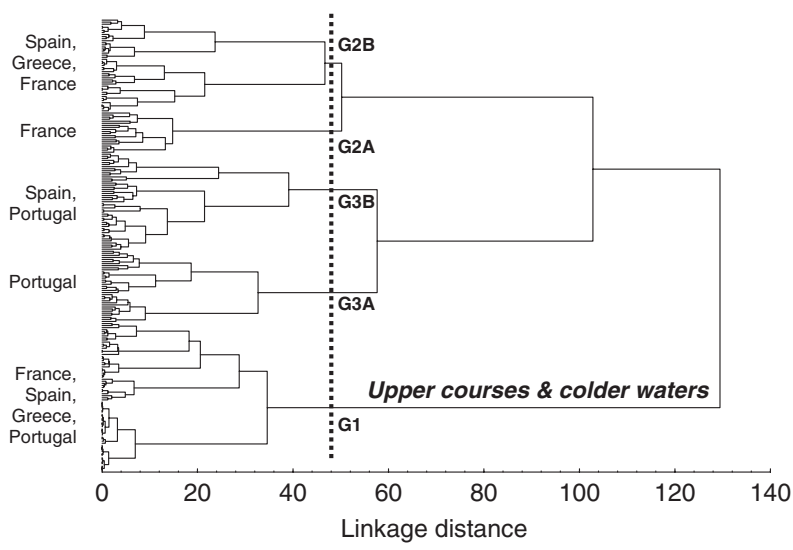

Figure 4. Fish-based groups for the Mediterranean calibration data set, using $\log X+1$-transformed abundances, squared Euclidian distance and Ward's clustering. All caps indicate a dominance of sites from a specific country.

responses were limnophilic, omnivorous and long-lived species (positive) for group 1 assemblages and tolerant species (positive), rheophilic and lithophilic species (negative) for group 2 assemblages. These metrics presented significant differences between calibration and non-calibration sites $(P<0.01)$. The feeding guild (e.g. influenced by introduced piscivorous species such as Micropterus salmoides (Lacépède, 1802)) and the tolerance guild (influenced by alien species such as C. carpio, L. gibbosus and Gambusia holbrooki Girard 1859) exhibited significant differences (Mann-Whitney $U$-tests, $P<0.05$ ) when all species and only native species were compared.

\section{Discussion}

Low species richness per site, a high degree of endemicity, as found in eastern Mediterranean fish assemblages, and basin-specific taxa assemblages, are problematic for developing biotic indices (Miller, Leonard, Hughes, Karr, Moyle, Shrader, Thompson, Daniels, Fausch, Fitzhugh, Gammon, Halliwell, Angermeier \& Orth 1988; Moyle \& Marchetti 1999). In Mediterranean Europe, additional difficulties include: (1) uncertainty about existing cyprinid taxa units; (2) insufficient knowledge of the ecological preferences of some species (e.g. Ribeiro, Cowx, Tiago, Filipe, Moreira da Costa \& Collares-Pereira 2003); and (3) a wide tolerance of many native taxa to abiotic variability (Granado-Lorencio 1996; Magalhães, Batalha \& Collares-Pereira 2002). Low richness per site is

Table 2. Frequency of occurrence (FO\%) and average relative abundance as species individuals ha ${ }^{-1}$ (RA\%) in each of the five fish types obtained in the cluster analysis using only calibration sites

\begin{tabular}{|c|c|c|c|c|c|c|c|c|c|c|}
\hline \multirow[b]{2}{*}{ Species } & \multicolumn{5}{|c|}{ FO $(\%)$ in each Fish Type } & \multicolumn{5}{|c|}{ RA $(\%)$ in each Fish Type } \\
\hline & G1 & G2A & G2B & G3A & G3B & G1 & G2A & G2B & G3A & G3B \\
\hline Anguilla anguilla $(\mathrm{L})$. & 19 & 35 & 31 & 9 & 28 & 3.9 & 1.2 & 11.9 & 0.5 & 0.3 \\
\hline Barbatula barbatula (L.) & 1 & 83 & 0 & 0 & 0 & 0.4 & 10.8 & 0 & 0 & 0 \\
\hline Barbus barbus (L.) & 3 & 45 & 11 & 0 & 0 & 0.7 & 9.1 & 1.1 & 0 & 0 \\
\hline Barbus bocagei Steindachner & 0 & 0 & 0 & 63 & 0 & 0 & 0 & 0 & 12.7 & 0 \\
\hline Barbus meridionalis Risso & 21 & 65 & 42 & 0 & 0 & 18.9 & 4.4 & 19.1 & 0 & 0 \\
\hline Barbus microcephalus Almaça & 0 & 0 & 0 & 0 & 34 & 0 & 0 & 0 & 0 & 21.4 \\
\hline Barbus peloponnesius Val. & 0 & 0 & 29 & 0 & 0 & 0 & 0 & 8.6 & 0 & 0 \\
\hline Barbus sclateri Günther & 0 & 0 & 0 & 0 & 60 & 0 & 0 & 0 & 0 & 3.2 \\
\hline Chondrostoma lemmingii Steindachner & 0 & 0 & 0 & 6 & 21 & 0 & 0 & 0 & 0.9 & 7.6 \\
\hline Chondrostoma polylepis Steindachner & 0 & 0 & 0 & 89 & 0 & 0 & 0 & 0 & 8.4 & 0 \\
\hline Chondrostoma willkommii Steindachner & 0 & 0 & 0 & 0 & 38 & 0 & 0 & 0 & 0 & 6.2 \\
\hline Cobitis paludica de Buen & 0 & 0 & 0 & 19 & 36 & 0 & 0 & 0 & 1.1 & 4.0 \\
\hline Cottus gobio (L.) & 10 & 15 & 6 & 0 & 0 & 12.6 & 9.6 & 0.6 & 0 & 0 \\
\hline Gobio gobio (L.) & 6 & 70 & 0 & 16 & 0 & 2.7 & 3.2 & 0 & 4.0 & 0 \\
\hline Lepomis gibbosus* (L.) & 0 & 5 & 0 & 9 & 30 & 0 & 0.4 & 0 & 13.6 & 0.9 \\
\hline Leuciscus carolitertii Doadrio & 0 & 0 & 0 & 28 & 0 & 0 & 0 & 0 & 16.8 & 0 \\
\hline Leuciscus cephalus (L.) & 1 & 95 & 73 & 0 & 0 & 0.5 & 6.2 & 12.0 & 0 & 0 \\
\hline Leuciscus pyrenaicus (Günther) & 0 & 0 & 0 & 60 & 62 & 0 & 0 & 0 & 15.8 & 4.2 \\
\hline Leuciscus souffia Risso & 3 & 65 & 9 & 0 & 0 & 1.5 & 23.9 & 12.8 & 0 & 0 \\
\hline Phoxinus phoxinus (L.) & 17 & 80 & 20 & 0 & 0 & 22.8 & 13.5 & 31.7 & 0 & 0 \\
\hline Salmo trutta fario (L.) & 100 & 90 & 20 & 50 & 0 & 36.1 & 17.7 & 2.5 & 5.7 & 0 \\
\hline Squalius alburnoides (Steindachner) & 0 & 0 & 0 & 53 & 45 & 0 & 0 & 0 & 20.2 & 52.1 \\
\hline
\end{tabular}

Only species with FO $>5 \%$ are shown. In italics, FO $>50 \%$ and RA $>17.5 \%$. Only calibration sites.

*Alien species. 



Figure 5. Variability in catchment area $\left(\mathrm{km}^{2}\right)$, mean air temperature $\left({ }^{\circ} \mathrm{C}\right)$, mean annual rainfall $(\mathrm{mm})$ and altitude $(\mathrm{m})$, for the five groups of sites obtained for the Mediterranean data set.

common in other European waters, especially upper rhithral streams (Melcher et al. 2007); their bioassessment relying upon absolute abundances of key (sentinel) species and other population parameters.

Many Mediterranean-type reaches include a high proportion of alien species (Moyle 1995; Aparicio, Vargas, Olmo \& Sostoa 2000; Corbacho \& Sánchez 2001; Kennard, Arthington, Pusey \& Harch 2005), and alien species were dominant over native populations at some weakly impacted sites, such as some salmonid streams from Greece (colonised mostly by Oncorhynchus sp. escaped from trout farms) and small lowland streams in Iberia. Factors important in the invasive process include human-driven dispersal, physical and biological characteristics of the aquatic systems, and different establishment phases of the alien species populations (Ross 1991; Lozon \& MacIsaac 1997; Meador, Brown \& Short 2003). However, it is not always easy to understand the relative contribution of each.

Whether or not alien species should be considered in ecological quality assessment in Mediterranean rivers is debatable. At the European level, metrics using only native species did not perform much better than the whole community response, but the number and abundance of alien species is generally lower and they are more widespread. In Iberia, however, some metrics responded to disturbance using only native taxa, namely species richness, abundance and individuals categorised as invertivorous, water column and phyt- ophylic (Ferreira et al. 2007). Kennard et al. (2005) demonstrated that alien fishes were good indicators of disturbance intensity in Mediterranean-like subtropical streams in Queensland, Australia, and can account for river health.

Considering the naturally small number of native species per site and the contribution to disturbance assessment of some alien species, should these be allowed on future metric indices? If the purpose of bioassessment, senso the Water Frame Directive (WFD; EC 2000), is to evaluate the status of ecosystems with the best and most reliable biological indicators, these should include aliens. Furthermore, from a practical point of view, it will be difficult to control longestablished alien species, which are virtually impossible to eradicate in most freshwater systems (Smith, Lonsdale \& Fortune 1999).

Metric responses to perturbation across Mediterranean areas were poor, and weaker than those used at the European level, both using fish-based or spatially based models (Pont et al. 2006; Melcher et al. 2007). Metric responses were also poorer in this large-scale Mediterranean bioassessment than previously found in smaller scale studies, in which fish types were obtained mostly at the basin level (Ferreira et al. 2007). Furthermore, local indices (frequently incorporating local expert knowledge of the species ecology) tend to perform better. In warm water streams of Virginia (USA), Angermeier \& Winston (1999) reported that each drainage-physiography combination supported a 
Table 3. Significant Spearman rank correlations $(P<0.05)$ between human pressure and selected metrics for the three major fishbased groups of sites (from Fig. 4) and for all Mediterranean sites pooled

\begin{tabular}{|c|c|c|c|c|}
\hline $\begin{array}{l}\text { Candidate } \\
\text { metrics }\end{array}$ & $\begin{array}{c}\text { Group 1 } \\
(n=235)\end{array}$ & $\begin{array}{l}\text { Group 2 } \\
(n=311)\end{array}$ & $\begin{array}{l}\text { Group } 3 \\
(n=371)\end{array}$ & $\begin{array}{c}\text { All } \\
(n=917)\end{array}$ \\
\hline \multicolumn{5}{|l|}{ Taxonomic } \\
\hline N_sp_all ${ }^{\dagger, *}$ & 0.19 & -0.12 & 0.12 & 0.11 \\
\hline N_sp_native $e^{\dagger, 末}$ & & -0.19 & & \\
\hline N_ha_sp_all ${ }^{\dagger, 末}$ & 0.24 & & & \\
\hline Perc_N_sp_total ${ }^{\dagger,+}$ & & & 0.28 & \\
\hline \multicolumn{5}{|l|}{ Tolerance } \\
\hline N_ha_sp_tol ${ }^{\dagger, 末}$ & 0.30 & & & 0.27 \\
\hline Perc_N_sp_intol ${ }^{\dagger, \S}$ & -0.32 & $-0.25^{*}$ & & $-0.31^{*}$ \\
\hline Perc_N_sp_tol ${ }^{\dagger, \S}$ & & $0.49 * *$ & & $0.39 * *$ \\
\hline \multicolumn{5}{|l|}{ Habitat } \\
\hline N_sp_li ${ }^{\dagger}$ & $0.35 * *$ & $0.26^{*}$ & & 0.18 \\
\hline N_sp_rh ${ }^{\dagger, \S}$ & & $-0.33^{* *}$ & & -0.09 \\
\hline N_sp_wc ${ }^{\dagger}$ & & -0.17 & & \\
\hline N_sp_b & 0.26 & & 0.12 & 0.16 \\
\hline N_ha_sp_b ${ }^{\dagger}$ & 0.29 & & & \\
\hline Perc_N_sp_rh ${ }^{\dagger}$ & -0.18 & $-0.58 * *$ & & $-0.34 * *$ \\
\hline Perc_N_sp_eury ${ }^{\dagger}$ & & $0.32 *$ & & 0.20 \\
\hline \multicolumn{5}{|l|}{ Reproduction } \\
\hline N_sp_lith ${ }^{\dagger}$ & 0.14 & $-0.31 *$ & -0.13 & -0.11 \\
\hline N_sp_phyt ${ }^{\dagger}$ & 0.15 & 0.14 & 0.24 & 0.24 \\
\hline Perc_N_ha_sp_lith $\$$ & -0.15 & $-0.50^{* *}$ & -0.23 & $-0.40^{* *}$ \\
\hline \multicolumn{5}{|c|}{ Feeding } \\
\hline N_sp_inse ${ }^{\dagger}$ & & -0.14 & & -0.18 \\
\hline N_sp_omni ${ }^{\dagger}$ & $0.34^{*}$ & & 0.16 & 0.17 \\
\hline N_ha_sp_omni ${ }^{\dagger, \downarrow, \S}$ & 0.23 & & & \\
\hline Perc_N_sp_omni ${ }^{\dagger}$ & $0.32 *$ & -0.12 & & 0.13 \\
\hline Perc_N_sp_inse ${ }^{\dagger}$ & -0.17 & -0.21 & -0.18 & $-0.31 *$ \\
\hline \multicolumn{5}{|l|}{ Life cycle } \\
\hline N_ha_sp_sl ${ }^{\dagger, 末}$ & 0.17 & & 0.14 & 0.10 \\
\hline N_ha_sp_ll ${ }^{\dagger}$ & 0.23 & & -0.11 & \\
\hline $\mathrm{N}_{-}^{-} \mathrm{sp}_{-}^{-} \mathrm{l}^{+}$ & $0.38 * *$ & & & 0.13 \\
\hline Perc_N_sp_sl ${ }^{\dagger}$ & & 0.14 & 0.21 & 0.07 \\
\hline Perc_N_sp_ll $1^{\dagger}$ & $0.35^{* *}$ & & -0.12 & 0.08 \\
\hline \multicolumn{5}{|l|}{ Migration } \\
\hline N_ha_sp_long ${ }^{\dagger}$ & -0.15 & & & 0.09 \\
\hline N_sp_pota ${ }^{\dagger, \S}$ & 0.30 & $-0.27 *$ & & \\
\hline N_sp_long ${ }^{\dagger, \S}$ & -0.20 & 0.16 & 0.19 & 0.20 \\
\hline Perc_N_N_sp_long ${ }^{\dagger}$ & -0.20 & $0.37^{* *}$ & 0.10 & 0.22 \\
\hline
\end{tabular}

Significant differences $\left({ }^{*} P<0.01\right.$ and $\left.* * P<0.001\right)$ between calibration and disturbed sites using Mann-Whitney $U$ rank tests.

${ }^{\dagger}$ Selected metrics for the European spatially based approach (Melcher et al. 2007).

${ }^{\ddagger}$ Selected metrics for the Iberian ecoregion (Ferreira et al. 2007).

${ }^{\S}$ Selected metrics for the European fish-based index (Pont et al. 2006).

distinctive type of fish community with particular metric responses. In Mediterranean-type stream ecosystems of California, metric response was dependent on site-specific characteristics of streams, resulting in distinct watershed-wide metrics (Moyle \& Randall 1998; Moyle \& Marchetti 1999).
In conclusion, there are considerable differences in fish community patterns between Mediterranean region and other parts of Europe. Moreover, there are also considerable within-region differences (particularly concerning the eastern Mediterranean area), related to micro-scale fluctuating environments, macro-scale landscape patchiness and ichthyo-geographic heterogeneity. Thus, it will be difficult to implement a fish-based approach at the large Mediterranean scale, with any degree of accuracy. Alternatively, the spatially based modelling approach may overcome these drawbacks. In both cases, metric reactions that can be used for quality assessment should be based in the abundance of the few native species present.

\section{Acknowledgments}

We thank Stefan Schmutz and his team for the coordination of the European FAME project (financed by the European Union, contract no. EVT1-CT-200100094); his encouragement and support made the development of the Mediterranean data set possible. We are also indebted to all people that have taken part in the data collection and graciously agreed to share their information.

\section{References}

Angermeier P.L. \& Winston M.R. (1999) Characterizing fish community diversity across Virginia landscapes: prerequisite for conservation. Ecological Applications 9, 335349.

Aparicio E., Vargas M.J., Olmo J.M. \& Sostoa A. (2000) Decline of native freshwater fishes in a Mediterranean watershed on the Iberian Peninsula: a quantitative assessment. Environmental Biology of Fishes 59, 11-19.

Beier U., Degerman E., Melcher A., Rogers C. \& Wirlöf H. (2007) Processes of collating a European fisheries database to meet the objectives of the European Union Water framework Directive. Fisheries Management and Ecology 14, 407-416.

Blondel J. \& Aronson J. (1999) Biology and Wildlife of the Mediterranean Region. Oxford: Oxford University Press, 328 pp.

CEN (2003) Water Quality - Sampling of Fish with Electricity. European standard - EN 14011:2003. Brussels: European Committee for Standardization, $18 \mathrm{pp}$.

Corbacho C. \& Sánchez J.M. (2001) Patterns of species richness and introduced species in native freshwater fish faunas of a Mediterranean-type basin: the Guadiana river (southwest Iberian Peninsula). Regulated Rivers: Research and Management 17, 699-707. 
Davies B.R., Thoms M.C., Walker K., O'Keefe F. \& Gore J.A. (1994) Dryland rivers: their ecology, conservation and management. In: P. Calow \& G.E. Petts (eds) The Rivers Handbook: Hydrological and Ecological Principles. Oxford: Blackwell Science, pp. 484-511.

Degerman E., Beier U., Breine J., Melcher A., Quataert P., Rogers C., Roset N. \& Simoens I. (2007) Classification and assessment of degradation in European running waters. Fisheries Management and Ecology 14, 417-426.

EU Water Framework Directive (2000) Directive 2000/60/ EC of the European Parliament and of the Council of 23 October 2000 establishing a framework for community action in the field of water policy. Official Journal of the European Communities (22.12.2000), L 327, 1.

Ferreira M.T., Cortes R.M., Godinho F.N. \& Oliveira J.M. (1996) Biological indicators of water quality applied to the Guadiana basin. Recursos Hidricos 17, 9-20 (in Portuguese).

Ferreira T., Caiola N., Casals F., Oliveira J.M. \& de Sostoa A. (2007) Assessing perturbation of river fish communities in the Iberian Ecoregion. Fisheries Management and Ecology 14, 519-530.

Gasith A. \& Resh V.H. (1999) Streams in Mediterranean climate regions: abiotic influences and biotic responses to predictable seasonal events. Annual Review of Ecology and Systematics 30, 51-81.

Granado-Lorencio C. (1996) Ecología de Peces. Sevilla: Secretariado de Publicaciones de la Universidad de Sevilla., 353 pp. (in Spanish).

Kennard M.J., Arthington A.H., Pusey B.J. \& Harch B.D. (2005) Are alien fish a reliable indicator of river health? Freshwater Biology 50, 174-193.

Lozon J.D. \& MacIsaac H.J. (1997) Biological invasions: are they dependent on disturbance? Environmental Reviews 5, 131-144.

Magalhães M.F., Batalha D.C. \& Collares-Pereira M.J. (2002) Gradients in stream fish assemblages across a Mediterranean landscape: contributions of environmental factors and spatial structure. Freshwater Biology 47, 10151031 .

Matthews W.J. \& Marsh-Matthews E. (2003) Effects of drought on fish across axes of space, time and ecological complexity. Freshwater Biology 48, 1232-1253.

Meador M.R., Brown L.R. \& Short T. (2003) Relations between introduced fish and environmental conditions at large geographical scales. Ecological Indicators 3, 81-92.

Melcher A., Schmutz S., Haidvogl G. \& Moder K. (2007) Spatially based methods to assess the ecological status of European fish assemblage types. Fisheries Management and Ecology 14, 453-463.

Miller D.L., Leonard P.M., Hughes R.M., Karr J.R., Moyle P.B., Shrader L.H., Thompson B.A., Daniels A.R, Fausch K.D., Fitzhugh G.A., Gammon J.R., Halliwell D.B.,
Angermeier P.L. \& Orth D.J. (1988) Regional applications of an index of biotic integrity for use in water resource management. Fisheries 13, 12-20.

Moyle P. (1995) Conservation of native freshwater fishes in the Mediterranean-type climate of California, USA: a review. Biological Conservation 72, 271-279.

Moyle P.B. \& Marchetti M.P. (1999) Applications of indices of biotic integrity to California streams and watersheds. In: T.P. Simon (ed.) Assessing the Sustainability and Biological Integrity of Water Resources Using Fish Communities. Boca Raton, FL: CRC Press, pp. 367-380.

Moyle P.B. \& Randall P.J. (1998) Evaluating the biotic integrity of watersheds in the Sierra Nevada, California. Conservation Biology 6, 1318-1326.

Noble R.A.A., Cowx I.G., Goffaux D. \& Kestemont P. (2007) Assessing the health of European rivers using functional ecological guilds of fish communities: standardising species classification and approaches to metric selection. Fisheries Management and Ecology 14, 381-392.

Oliveira J.M. \& Ferreira M.T. (2002) Development of an index of biotic integrity to assess environmental quality in warmwater streams. Revista de Ciências Agrárias 25, 198210 (in Portuguese).

Pires A.M., Cowx I.G. \& Coelho M.M. (2001) Diet and growth of two sympatric Iberian barbel, Barbus steindachneri and Barbus microcephalus, in the middle reaches of the Guadiana Basin (Portugal). Folia Zoologica 50, 291-304.

Pont D., Hugueny B., Beier U., Goffaux D., Melcher A., Noble R., Rogers C., Roset N. \& Schmutz S. (2006) Assessing river biotic condition at a continental scale: a European approach using functional metrics and fish assemblages. Journal of Applied Ecology 43, 70-80.

Ribeiro F., Cowx I.G., Tiago P., Filipe A.F., Moreira da Costa L. \& Collares-Pereira M.J. (2003) Growth and reproductive traits of diploid and triploid forms of the Squalius alburnoides cyprinid complex in a tributary of the Guadiana River, Portugal. Archiv für Hydrobiologie 156, 471-484.

Roset N., Grenouillet G., Goffaux D., Pont D. \& Kestemont P. (2007) A review of existing fish assemblage indicators and methodologies. Fisheries Management and Ecology 14, 393-405.

Ross S.T. (1991) Mechanisms structuring fish assemblages: are there lessons from introduced species? Environmental Biology of Fishes 30, 359-368.

Smith C.S., Lonsdale W.M. \& Fortune J. (1999) When to ignore advice: invasion predictions and decision theory. Biological Invasions 1, 89-96.

Vila-Gispert A., Moreno-Amich R. \& García-Berthou E. (2002) Gradients of life-history variation: an inter-continental comparison of fishes. Reviews in Fish Biology and Fisheries 12, 417-427. 